\title{
The Relationship between Work Commitment, Work Discipline and Inter- personal Communication with Teacher Work Morale at Elementary Schools in Daha Selatan District
}

\author{
Asy'ari *, Mahrita, Juhriyansyah Dalle \\ Master Program of Education Management, Universitas Lambung Mangkurat, Banjarmasin 70123, \\ Indonesia
}

\section{Article history:}

Submission December 2020

Revised April 2021

Accepted April 2021

*Corresponding author:

E-mail: Asyari90@gmail.com

\begin{abstract}
Morale is an effort to maximize work, resulting in success. Teachers need enthusiasm in working so that school goals can be achieved. Many factors influence morale. Therefore, this study aims to determine the relationship between work commitment, work discipline, and interpersonal communication with teachers' morale in public elementary schools by describing and analyzing them. This study used path analysis with a sample of 139 teachers from a population of 220 Public Elementary School teachers in Daha Selatan District. Data were collected through questionnaires and analyzed using multiple regression methods. The results show that the relationship between work commitment, work discipline, and interpersonal communication with teachers' work morale is very high. It can be concluded that work commitment, work discipline, and interpersonal communication affect teachers' morale. Other schools can use the results of this study to increase teachers' morale at school.
\end{abstract}

Keywords: Work commitment, work discipline, interpersonal communication, spirit at work

\section{Introduction}

Education changes the human mindset developing, along with technological advances, the excellence of human resources becomes the main thing in an organization. The success of an organization lies in the role of human resources (Izvercian et al., 2014). School, as an organization, has goals to be achieved. Therefore, competent teachers are needed to produce better school performance (Bacher-Hicks et al., 2019; Molina et al., 2020).
One of the things that can cause teachers to work optimally is to increase teacher morale. Morale is needed as a desire and sincerity in doing his job. Work morale positively affects an organization's productivity (Mallik et al., 2019). Thus, if the employees' work morale is low, it will make the organization's performance low as well (Anjum et al., 2018; Sabitova et al., 2020). Teachers who experience morale will be manifested in their attitudes or actions. In carrying out his daily

\section{How to cite:}

Asy'ari. (2021). The relationship between work commitment, work discipline and interpersonal communication with teacher work morale at Elementary Schools in Daha Selatan District. Journal of K6 Education and Management, 4 (1), 71 - 80. doi: 10.11594/jk6em.04.01.07 
work, a teacher must have work morale (Noor et al., 2019).

According to Gorton (1972), the teacher's morale will have the enthusiasm and ability to carry out his duties to achieve organizational goals. Therefore, teachers' morale significantly affects teachers' performance (Sehang et al., 2017).

Morale is a person's willingness to work actively and enthusiastically to work faster and better (Hasibuan, 2010). According to Purwanto (2012), morale is an emotional and mental reaction from a person to his job, thus causing deep pleasure to achieve the organization's goals. Teachers' morale has something to do with job satisfaction, teachers' commitment, teachers' needs, and perceived realization of those needs (Erichsen \& Reynolds, 2020; Willis \& Varner, 2010).

According to Yulianti \& Muhidin (2017), morale is a spiritual condition or work behavior of individual groups that creates deep pleasure in workers to work diligently and achieve the organization's goals. According to Sastrohardiyo (2002), morale is individual behavior that causes deep satisfaction in the workforce to work harder and the consequences in achieving the goals set by the organization. According to Nawawi (2006) states that the indicators of morale are: (a) Sincerity, (b) Excitement, (c) Friendliness, (d) Cooperation, (e) Doing innovation, (f) Maintaining Ethics.

Morale is a behavior shown by a person or group of people towards the workplace to show the extent of passion in carrying out their duties and responsibilities within the organization. Morale can be formed from a conducive work commitment. Optimal work spirit is generated by full work commitment (Parmin, 2013). Thus, optimal work commitment can lead to optimal morale as well. According to Suriansyah (2014), commitment is built from desires, obligations, and organizational members' needs. A teacher's desire to remain in the school organization will create high enthusiasm in carrying out its duties as a teacher because it is a need that the organization needs. According to Suhaimi (2015) Work commitment is an element of behavior used to remain a member of the organization. Work commitment is one of the keys that the dean organization's success or failure to achieve its goals (Parmin, 2013). According to Pugach (Kusrini et al., 2018), teachers' work commitment means that teachers actively contribute to their profession. Work commitment is an attachment to duties and obligations that lead to teacher responsibility (Suriansyah, 2014). A good teacher is a professional with a high level of work commitment (Rosyada, 2020).

According to Sopiah (2008), there are three indicators in a teacher work commitment, namely: (a) Continuous commitment, in the form of teachers paying full attention to school development, prioritizing school progress, and being willing to make sacrifices for the benefit of the school, (b) cohesion commitment, in the form of upholding professional norms, prioritizing actions that are useful and develop a harmonious relationship in the school environment, (c) controlled commitment, in the form of behaving well as a teacher, providing good examples in the school environment and providing useful input about something good in the school environment.

Morale is a way of seriousness in the discipline. According to Hasibuan (2013), morale is the desire and sincerity of a person to work in a disciplined manner. Discipline is an action that shows orderly behavior and complies with various rules and regulations (Suhaimi \& Rinawati, 2018). Disciplined will also get used to complete all tasks on time. Discipline includes respect and obedience to agreements made by organizations and employees. According to Susipta (2015), discipline is one factor that can be used to measure morale. Discipline is an attitude and behavior following administrative regulations, both in written and unwritten form. Discipline is the process of training employees to control their emotions and work optimally (Harahap et al., 2020). High discipline tends to make teachers work better (Sulaxono, 2020). Teacher discipline in work can be a mental attitude reflected in the actions and behavior of a teacher. To build teacher work discipline, 
schools must create environments that support this behavior (Nisa, 2020). To maximize teachers' work, teachers must instill a spirit of discipline in their work (Hairina, 2020; Kelimeda et al., 2018). According to Pratama (2019), stated that there are several indicators of employee work discipline, namely: (a) Timeliness, (b) Using office equipment well, (c) High responsibility, (d) Obedience to official rules.

One of the factors that can increase morale is communication (Nitisemito, 2008)). Communication is one of the needs of humans as social beings (Rahmadani, 2020). Good communication can encourage openness and direction (Setyawati, 2020). By creating excellent communication, every problem will be resolved properly (Ruslan, 2020). Communication occupies a significant place because the composition of the organization's breadth and scope as a whole is determined by communication techniques (Suhaimi \& Efendi, 2018). Effective communication is communication that shows a feedback mechanism. Every human being needs communication to talk, exchange opinions, share experiences, and collaborate with other people in the social system, including the educational and organizational systems (Suranto, 2005). With good communication, connections between co-workers will make morale increase so that it is profitable for schools. Organizations also need communication with subordinates about their job assignments (Mulyasa, 2012). A teacher's ability to communicate is necessary; both communication between teachers and teacher communication between students (Suhaimi \& Rinawati, 2018). With an equal distribution of tasks through communication, the task will be completed appropriately because it follows the teacher's fields and abilities.

Several forms of communication can be used according to their needs to create an effective and efficient organization. One of the communication is interpersonal communication (Handoko, 2003). Interpersonal communication is a face-to-face interaction between two or more people where the sender can convey messages directly. The message recipient can receive and respond to messages directly (Suyomukti, 2016). Interpersonal communication can affect employees' smoothness of work and teacher morale in carrying out their respective duties (Nasrullah, 2012). Interpersonal communication between teachers that occurs in schools will encourage morale so that it impacts school work's smoothness, which will realize the success of school goals.

The interpersonal communication indicators can be seen from interpersonal communication effectiveness. The effectiveness of interpersonal communication has five characteristics, namely: (a) Openness, willingness to respond happily to information received in dealing with interpersonal relationships, (b) Empathy (empathy), feeling what others feel, (c) Support ( supportiveness), an open situation to support effective communication, (d) positive feeling (positiveness), a person must have a positive sense of himself, encourage others to participate more actively and create communication conducive to effective interaction, (e) equality, a tacit acknowledgment that both parties value, are useful, and have something important to contribute.

\section{Material and Methods}

A good methodology will provide good results for the research objectives (Dalle, 2010). This research was conducted with a descriptive-quantitative approach because the data obtained were in the form of numbers. The processing was carried out by statistical methods, after which interpretation was carried out. The descriptive method provides a description or relationship of the problem to be solved (Nazir, 2005). Quantitative methods to describe a symptom through quantitative analysis with mean scores and graphs and make predictions and estimates based on predetermined models and analysis results (Arikunto, 2011). The technique used in this research is correlational. According to Arikunto (2010), correlational research aims to determine whether there is a relationship between two variables or several variables. The relationship between variables based on theory and previous research and empirical 
data (Cooper \& Schindler, 2014). The instrument used in this study was a questionnaire that contained several statements and several answers that the respondents could choose from. The questionnaire contains four variables studied, namely work commitment (X1), work discipline (X2), interpersonal communication $(\mathrm{Z})$, and teacher morale $(\mathrm{Y})$. The sample used in this study were 139 public elementary school teachers in Daha Selatan district, Hulu Sungai Selatan district. The data obtained from the questionnaire were then analyzed using SSS version 23 .

\section{Results and Discussion \\ Characteristic of respondent}

The characteristics of the respondents in this study were the employment status of the respondents (ASN as much as $53.237 \%$ and non-ASN as much as $46.763 \%$ ); gender of respondents (male as much as $35.971 \%$ and $64.029 \%$ female); the age of respondents (2130 years as much as $41.726 \%$; $31-40$ years as much as $33.813 \%$; $41-50$ years as many as $12.950 \%$ and $>50$ years as many as $11.511 \%$ ); working period of respondents $(0-5$ years as much as $43.165 \%$; 6-10 years as much as $14.389 \%$; $11-15$ years as much as $26.619 \%$ and $>$ 15 years as much as $15.827 \%$ ); education level of respondents (SMA / SPG as much as $5.036 \%$, D2 as much as $3.597 \%$, S1 as much as $90.648 \%$ and S2 as much as $0.719 \%$ ); income (certification as much as $30.216 \%$ and not certification as much as $69.784 \%$ )

\section{Variable description results}

This research questionnaire consisted of several statements containing four research variables. Each variable statement is described as a score with the highest score of five and the lowest score of one. The distribution of the work commitment variable score (X1) is a total average score of 3,823 in the high category. The distribution of the score for the work discipline variable (X2), namely the total average score of 3,415 in the high category. The distribution of scores for the interpersonal communication variable $(Z)$ is a total average score of 3,840 in the high category. The distribution of the teacher morale $(\mathrm{Y})$ variable score, with the total average score of 4.031 , is categorized as a very high category. From all the variable score distribution results, it can be concluded that the highest average score is the morale variable with a very high category.

\section{Testing requirements analysis \\ Normality test}

The normality test is carried out to determine whether the data is normally distributed or not. The normality test used in this study is the Kolmogorov-Smirnov test (Sugiyono, 2013). The data is said to be normally distributed if the significant value is greater than 0.05 . Conversely, if the significant value is less than 0.05 , it can be said that the data is not normally distributed.

Table 1 . Tests of normality

\begin{tabular}{lrrrrrrr}
\hline & \multicolumn{3}{c}{ Kolmogorov-Smirnova } & \multicolumn{3}{c}{ Shapiro-Wilk } \\
\cline { 2 - 8 } & Statistics & Df & Sig. & Statistics & df & Sig. \\
\hline Work_commitment &, 058 & 139 &, $200 *$ &, 974 & 139 &, 008 \\
Work_Discipline &, 070 & 139 &, 092 &, 991 & 139 &, 495 \\
Interpersonal_Communication &, 075 & 139 &, 056 &, 985 & 139 &, 122 \\
Teacher_Work_Morale &, 051 & 139 &, $200 *$ &, 991 & 139 &, 503 \\
\hline
\end{tabular}

From table 1, we can see in the Kolmogorov-Smirnov section that all research variables have a significant value of more than 0.05 with details of work commitment (X1) 0.200; work discipline (X2) 0.092; interpersonal communication $(Z) 0.056$ and teacher morale (Y) 0.200 , it can be concluded that all research variables are normally distributed. 


\section{Linearity test}

The research data is said to be linear if the significance value is less than 0.05 . This test is used as a requirement in correlation analysis or linear regression (Priyatno, 2010).

Table 2. Linearity test

\begin{tabular}{cccc}
\hline No. & Variable & Linearity & Information \\
\hline 1. & $\mathrm{X} 1$ and $\mathrm{Z}$ & 0,000 & Linear \\
2. & $\mathrm{X} 2$ and $\mathrm{Z}$ & 0,000 & Linear \\
3. & $\mathrm{X} 1$ and $\mathrm{Y}$ & 0,000 & Linear \\
4. & $\mathrm{X} 2$ and $\mathrm{Y}$ & 0.008 & Linear \\
5. & $\mathrm{Z}$ and $\mathrm{Y}$ & 0,000 & Linear \\
\hline
\end{tabular}

In table 2, the variable work commitment (X1) with interpersonal communication (Z); work discipline variable $(X 2)$ with interpersonal communication (Z); work commitment variable $(\mathrm{X} 1)$ with morale $(\mathrm{Y})$; work discipline variable $(\mathrm{X} 2)$ with morale $(\mathrm{Y})$; interpersonal communication variable $(\mathrm{Z})$ with morale $(\mathrm{Y})$. All variables have a significant value of 0.000 ,

Table 3. Homogeneity test

No.

\begin{tabular}{cccc} 
No. & Variable & P-value / sig & Information \\
\hline 1. & $\mathrm{X} 1$ and $Z$ & 0.074 & Homogenous \\
2. & $\mathrm{X} 2$ and $Z$ & 0.138 & Homogenous \\
3. & $\mathrm{X}$ 1 and $\mathrm{Y}$ & 0.400 & Homogenous \\
4. & $\mathrm{X} 2$ and $\mathrm{Y}$ & 0.495 & Homogenous \\
5. & $\mathrm{Z}$ and $\mathrm{Y}$ & 0.325 & Homogenous \\
\hline
\end{tabular}

which means less than 0.05 , so it can be concluded that the data is linearly distributed.

\section{Homogeneity test results}

The research variable is said to be homogeneous if it has a significant value greater than 0.05 . Conversely, if the significant value is less than 0.05 , the research variable is said to be not homogeneous.

Table 3 shows that all research variables have a significant value of more than 0.05 , so it can be concluded that all research variables are homogeneous.

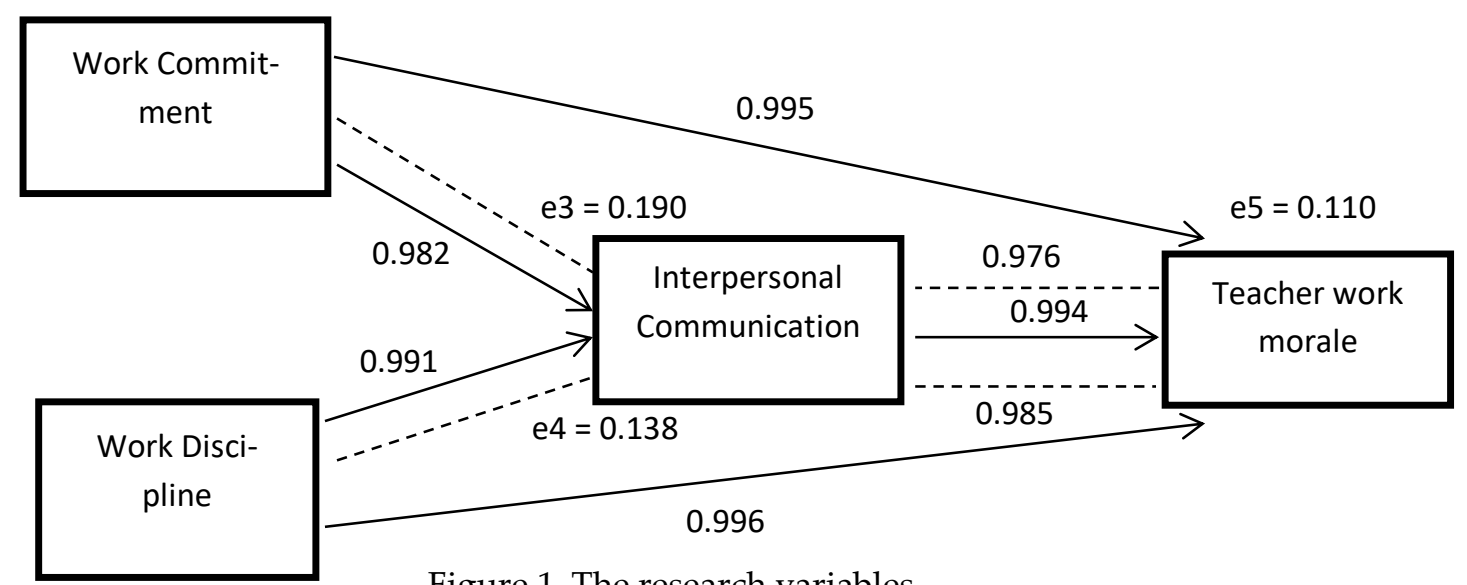

Figure 1. The research variables 
Relationship between work commitment and work morale

The $\mathrm{t}$-value of the work commitment and work morale variables is 112.815 . This value is greater than the t-table 1,977. It can be concluded that there is a direct relationship between work commitment and morale. In Figure 1 , it is known that the relationship between work commitment and morale is 0.995 . This indicates that the relationship is in a very strong category. This result is reinforced by previous studies' results, which state a direct relationship between work commitment and teacher morale (Suhaimi, 2015). Besides, work commitment is also reported to have a strong relationship to work motivation (Meyer et al., 2004; Shaban et al., 2017; Robescu \& Lancu, 2016). Furthermore, work commitment and motivation will influence employee productivity. An employee with high morale is normally happy and satisfied with his or her job (Kanimozhi \& Vinothkumar, 2018). Besides, high morale will increase the employees' works (Weakliem \& Frenkel, 2006).

\section{The relationship between work discipline and morale}

The value of $\mathrm{t}$-count on the variables of work discipline and morale is 123.772 . This value is greater than the t-table 1,977; it can be concluded that there is a direct relationship between work discipline and morale. In Figure 1 , it is known that the relationship between work discipline and morale is 0.996 . This shows that the relationship falls into a very strong category. Work discipline has a strong relationship to work morale because work discipline has been proven to have a positive effect on job satisfaction (Jayanti et al., 2020; Mangkunegara \& Octorend, 2015; Sohail et al., 2014). At the same time, satisfaction is an indicator of work morale (Jewcyzn, 2010; Sania et al., 2015).

\section{The relationship between work commitment and interpersonal communication}

The $t$-value for work commitment and interpersonal communication variables is 60.390. This value is greater than the $t$-table 1,977 ; it can be concluded that there is a direct relationship between work commitment and interpersonal communication. Figure 1 shows that the relationship between work commitment and interpersonal communication is 0.982 . This shows that these relationships fall into a very strong category. This study's result is also supported by the previous studies that have proven that interpersonal communication has a relationship with work commitment (Wahyuni et al., 2016; Nofia et al., 2019). It was also found that interpersonal communication correlates with work satisfaction (Awad \& Alhashemi, 2012). Good communication among the organization members will create a good situation that makes them feel happy and reduce work stress (Sageer \& Rafat, 2012; Nappo, 2020).

\section{The relationship between work discipline and interpersonal communication}

The $t$-value for work discipline and interpersonal communication variables is 84.571 . This value is greater than the t-table 1,977 . It can be concluded that there is a direct relationship between discipline and interpersonal communication. Figure 1 shows that the relationship between work discipline and interpersonal communication is 0.991. This shows that the relationship is in a very strong category. Both work discipline and interpersonal communication have a significant role in the organization's performance (Okoro et al., 2017; Szostek, 2019; Poernamawijayai et al., 2018). Since they have an important role and have a strong relationship, it is a must for all school staff to maintain and improve their work discipline and interpersonal communication.

\section{The relationship between interpersonal com- munication and morale}

The $t$-value of the interpersonal communication and work morale variables is 107.352. This value is greater than the t-table 1,977; it can be concluded that there is a direct relationship between interpersonal communication and morale. Interpersonal communication will influence the relationships among the organization members. It means that it may trigger conflict or create a good situation 
(Bao et al., 2016). It depends on the quality of interpersonal communication.

\section{Indirect relationship work commitment with morale through interpersonal communica- tion}

This indirect relationship is obtained by multiplying the direct relationship between work commitment and interpersonal communication (P3) with the coefficient of the direct relationship between interpersonal communication and work morale (P5). Obtained an indirect relationship $(0.982 \times 0.994)=0.976$. This shows that the indirect relationship falls into a very strong category with an error level of 0.190 .

The value of $\mathrm{t}$-count in this indirect relationship is $\mathrm{t}=, \frac{P 35}{S e 35}$

Se35 $=\sqrt{ }$ P52. Se32 + P32. Se52 + Se32. Se52

$\sqrt{(0,988) \cdot\left(4 \cdot 10^{-4}\right)+(0,964) \cdot\left(64 \cdot 10^{-6}\right)+\left(4 \cdot 10^{-4}\right) \cdot\left(64 \cdot 10^{-6}\right)}$

Se35 $=0.021$

$\mathrm{t}=\frac{P 35}{S e 35}=\frac{0,976}{0,021}=46.476$

The $t$-count value of 46.476 is greater than the $\mathrm{t}$-table 1.977, so it can be concluded that there is an indirect relationship between work commitment and morale through interpersonal communication.

The indirect relationship between work discipline and morale through interpersonal communication

This indirect relationship is obtained by multiplying the coefficient of the direct relationship between work discipline and interpersonal communication (P4) with the coefficient of the direct relationship between interpersonal communication and work morale (P5). Obtained an indirect relationship (0.991 $x 0.994)=0.985$. This shows that the indirect relationship falls into a very strong category with an error level of 0.138 .

The value of $\mathrm{t}$-count in this indirect relationship is $\mathrm{t}=, \frac{P 45}{S e 45}$

$$
\text { Se45 }=\sqrt{ } \text { P52. Se42 }+ \text { P42. Se } 52+\text { Se42. Se } 52
$$

Se $45=0.080$

$\mathrm{t}=\frac{P 45}{\operatorname{Se} 45}=\frac{0,985}{0,080}=12,312$

The $t$-count value of 12.312 is greater than the t-table 1.977, so it can be concluded that there is an indirect relationship between work discipline and morale through interpersonal communication.

\section{Conclusion}

This research concludes that work commitment, work discipline, and interpersonal communication have a strong direct and indirect relationship to Teacher Work Morale. Since all of those variables are important to the school's performance, teachers in the Daha Selatan district are expected to work seriously to get maximum results to achieve school goals. The seriousness of the teacher in working can be seen from the morale of the work. Some other variables also may influence the teachers' work morale. Thus, a further study that involves other variables is needed to be conducted.

\section{Acknowledgment}

The authors say thanks to the Master Program of Education Management, Universitas Lambung Mangkurat, Banjarmasin 70123, Indonesia, for supporting this research.

\section{References}

Anjum, A., Ming, X., Siddiqi, A. F., \& Rasool, S. F. (2018). An empirical study analyzing job productivity in toxic workplace environments. International Journal of Environmental Research and Public Health, 15(35), 1-15. doi:10.3390/ijerph15051035

Arikunto, S. (2010). Research procedure. Jakarta: PT. Rineka Cipta.

Arikunto, S. (2011). Research procedure: A practice approach. Jakarta: PT. Renika Cipta.

Awad, T. A., \& Alhashemi, S. E. (2012). Assessing the effect of interpersonal communications on employees' commitment and satisfaction. International Journal of Islamic and Middle Eastern Finance and Management, 5(2), 134-156. doi:10.1108/17538391211233425

Bacher-Hicks, A., Chin, M. J., Kane, T. J., \& Staiger, D. O. (2019). An experimental evaluation of three teacher quality measures: Value-added, classroom observations, and $\sqrt{(0,988) \cdot\left(144 \cdot 10^{-6}\right)+(0,982) \cdot\left(64 \cdot 10^{-6}\right)+\left(144 \cdot 10^{-6}\right) \cdot\left(64 \cdot 10^{-6}\right)}$ 
student surveys. Economics of Education Review, 73, 1-17. doi:https://doi.org/10.1016/j.econedurev.2019.101919

Bao, Y., Zhu, F., Hu, Y., \& Cui, N. (2016). The research of interpersonal conflict and solution strategies. Psychology, 7, 541-545. doi:http://dx.doi.org/10.4236/psych.2016.74055

Cooper, D., \& Schindler, P. (2014). Business research methods. New York: McGraw-Hill Education.

Dalle, J. (2010). General methodology of inquiry crowding out inner and outer assessment: a case study of the indonesia student enrollment system. Kedah: Universiti Utara Malaysia.

Erichsen, K., \& Reynolds, J. (2020). Public school accountability, workplace culture, and teacher morale. Social Science Research, 85, 1-15. doi:https://doi.org/10.1016/j.ssresearch.2019.102347

Gorton, R. (1972). School administration and supervision. Iowa: Wm.C. Brown company publishers.

Hairina, D. (2020). The relationship of emotional intelligence and work motivation through work discipline on the performance of state vocational high school teachers in Banjarmasin city. Journal of K6 Education and Management, 3(3), 327-341. doi:https://jk6em.org/index.php/jkemorg/article/view/401

Handoko, T. (2003). Management Personalia and human resources. Yogyakarta: BPFE.

Harahap, M. E., Suriansyah, A., \& Suhaimi. (2020). Relationship of instructional leadership, organizational climate and teacher's commitment to job satisfaction. Journal of K6 Education and Management, 2(4), 260-270. doi:https://doi.org/10.11594/jk6em.02.04.01

Hasibuan, M. (2010). Organizational motivation. Jakarta: Bumi Aksara.

Hasibuan, M. (2013). Human resource management. Jakarta: PT. Bumu Aksara.

Izvercian, M., Radu, A., LarisaIvascu, \& Ardelean, B.-O. (2014) The impact of human resources and total quality management on the enterprise. Procedia - Social and Behavioral Sciences, 124, 27-33. doi:https://doi.org/10.1016/j.sbspro.2014.02.456

Jayanti, E., Utaminingtyas, R. R., \& Farouk, U. (2020). The effect of work motivation, work discipline, and work environment on employee job satisfaction at PT. Samudera Perdana Selaras. Admisi dan Bisnis, 21(2), 131142 .

Kanimozhi, M., \& Vinothkumar, A. (2018). Effectiveness of employee morale and its impact on employee relation in manufacturing industry. Journal of Emerging Technologies and Innovative Research, 5(11), 506-512.

Kelimeda, Hairudinor, Ridwan, M. N., \& Dalle, J. (2018). The effect of motivation, job satisfaction and job discipline toward employee performance of PT. Buma Perindahindo at Lng Tangguh Site, Teluk Bintuni Regency, West Papua, Indonesia. European Journal of Human Resource Management Studies, 2(1), 49-73. doi:http://dx.doi.org/10.5281/zenodo.2040456

Kusrini, L., Suriansyah, A., \& Saleh, M. (2018). the influence of supervision of academic supervisors with commitment and work motivation on performance of teachers of the state high school in Banjarmasin, Indonesia. European Journal of Education Studies, 5(7). doi:http://dx.doi.org/10.46827/ejes.v0i0.2098

Mallik, A., Mallik, L., \& Keerthi, D. (2019). Impact of employee morale on organizational success. International Journal of Recent Technology and Engineering, 8(4), 3289-3293. doi:10.35940/ijrte.D8070.118419

Mangkunegara, A. P., \& Octorend, T. R. (2015). Effect of work discipline, work motivation and job satisfaction on employee organizational commitment in the company (Case Study in PT. Dada Indonesia). Universal Journal of Management, 3(8), 318-328. doi:10.13189/ujm.2015.030803

Meyer, J. P., Becker, T. E., \& Vandenberghe, C. (2004). Employee commitment and motivation: A conceptual analysis and integrative model. Journal of Applied Psychology, 89(6), 991-1007. doi: 10.1037/00219010.89.6.991

Molina, E., Fatima, S. F., Ho, A. D., Melo, C., Wilichowski, T. M., \& Pushparatnam, A. (2020). Measuring the quality of teaching practices in primary schools: Assessing the validity of the Teach observation tool in Punjab, Pakistan. Teaching and Teacher Education, 1-19. doi:https://doi.org/10.1016/j.tate.2020.103171

Mulyasa. (2012). Character education management. Jakarta: PT. Bumi Aksara.

Nappo, N. (2020). The interactive effect of cojob stress and interpersonal relationships cross country evidence from the EU15: A correlation analysismmunication and stress on perception of quality of work life. BMC Public Health, 20, 1-11. doi:https://doi.org/10.1186/s12889-020-09253-9

Nasrullah, R. (2012). Intercultural communication (in the cultural cyber). Jakarta: Prenada Media Group.

Nawawi, H. (2006). Performance evaluation and supervision. Yogyakarta: Gajah Mada Offset.

Nazir, M. (2005). Research methods. Jakarta: Ghalia Indonesia.

Nisa, W. (2020). The contribution of professional competence through the work discipline and performance to teacher work productivity in public elementary school of savings subdistrict, Barito Kuala. Journal of K6, Education, and Management,3(1), 149-157.

Nitisemito, A. (2008). Management personalia. Jakarta: Adisi Indonesia. 
Nofia, D., Yasri, Y., \& Abror, A. (2019). The effects of interpersonal communication and organizational commitment on organizational citizenship behavior (at Agam District Government). Advances in Economics, Business and Management Research, 97, 581-587.

Noor, S., Wahyu, \& Suhaimi. (2019). Relationship principal leadership to work motivation, morale teacher and teacher performance of state junior high schools. Journal of K6, Education, and Management, 2(1), 15-22.

Okoro, E., Washington, M. C., \& Thomas, O. (2017). The impact of interpersonal communication skills on organizational effectiveness and social self-efficacy: A Synthesis. International Journal of Language and Linguistics, 4(3), 2832.

Parmin. (2013). The influence of leadership and satisfaction on employee morale with organizational commitment asan intervening variable. Journal Manajemen Pendidikan, 1.

Poernamawijayai, L. W., Sulaiman, Suriansyah, A., \& Dalle, J. (2018). Contribution on supervision of supervisor, principals motivation, kindergarten teacher performance to improving the kindergarten quality in West Banjarmasin, Indonesia. European Journal of Alternative Education Studies, 3(2), 129-146. doi:10.5281/zenodo. 226103

Pratama, M. (2019). The influence of leadership, work motivation and work discipline on employee performance of the central sumatra region of Sungai Sumatra $V$. Medan: State University of North Sumatera.

Priyatno, D. (2010). Easy and fast techniquest to analyze research data with SPSS and questions and answers on awareness exams Pendadaran. Yogyakarta: Gaya Media.

Purwanto. (2012). Workforce management. Bandung: Pioneer.

Rahmadani, I. (2020). Contribution of teachers perceptions about the effectiveness of principal leadership and interpersonal communication on school climate through emotional intelligence. Journal of K6 Education and Management, 3(3), 295-302.

Robescu, O., \& Iancu, A.-G. (2016). The effects of motivation on employees performance in organizations. Valahian Journal of Economic Studies, 1-8. doi:10.1515/vjes-20160006

Rosyada, A. (2020). Contribution of organizational commitment, lesson study and teacher professionalism to learning quality. Journal of K6, Education, and $\begin{array}{llll}\text { Management, } & 3(2), & 118- & \end{array}$ doi:http://dx.doi.org/10.11594/jk6em.03.02.03

Ruslan, M. (2020). Contribution of Principal Transformational Leadership and Interpersonal Communication through Work Motivation on Teacher Performance at all State Junior High Schools in Banjarmasin Utara Sub-district.
Journal of K6 Education and Management, 3(2), 178-186. doi:https://doi.org/10.11594/jk6em.03.02.09

Sabitova, A., Hickling, L. M., \& Priebe, S. (2020). Job morale: A scoping review of how the concept developed and is used in healthcare research. BMC Public Health, 20, 1-9. doi:10.1186/s12889-020-09256-6

Sageer, A., \& Rafat, S. (2012). The interactive effect of communication and stress on perception of quality of work life. IOSR Journal of Business and Management, 4(6), 29-31.

Sania, U., Kalpina, K., \& Javed, H. (2015). Diversity, employee morale and customer satisfaction: The three musketeers. Journal of Economics, Business and Management, 3(1), 11-18. doi:10.7763/JOEBM.2015.V3.147

Sastrohadiwiryo, S. (2002). Indonesia workforce management: Administrative and operational approaches. Jakarta: Bumi Aksara.

Sehang, F., Rawis, J. A., Simandjuntak, S., \& Kambey, D. (2017). Relationship between Morale and the Teacher Performance at Adventist Junior High School of North Sulawesi Province. IOSR Journal of Research \& Method in Education, 7(4), 23-28. doi:10.9790/7388-0704042328

Setyawati, N. S. (2020). The influence of parents' role and parenting on communication and social independence of children in Kindergarten Cempaka Cluster, Central Banjarmasin Subdistrict. Journal of K6 Education and Management, 3(1), 66-73. doi:https://doi.org/10.11594/jk6em.01.01.09

Shaban, O. S., Al-Zubi, Z., Ali, N., \& Alqotaish, A. (2017). The effect of low morale and motivation on employees' productivity \& competitiveness in Jordanian Industrial Companies. International Business Research, 10(7), 1-17. doi:https://doi.org/10.5539/ibr.v10n7p1

Sohail, A., Safdar, R., Saleem, S., Ansar, S., \& Azeem, M. (2014). Effect of work motivation and organizational commitment on job satisfaction: (A case of education industry in Pakistan). Global Journal of Management and Business Research: A Administration and Management, 16(6), 1-7.

Sopiah. (2008). Organizational behavior. Yogyakarta: Andi.

Sugiyono. (2013). Research methods quantitative qualitative RED. Bandung: Alfabeta.

Suhaimi. (2015). The relationship between principal leadership behavior, morale, organizational commitment and. Malang: State University of Malang.

Suhaimi, \& Rinawati, Y. (2018). The management of character education curriculum at Vocational High School 2 Kandangan. 274, 272-277. doi:https://doi.org/10.2991/iccite-18.2018.59 
Suhaimi, S., \& Efendi, N. (2018). The relationship between the role of the principal and attitudes towards the teaching profession with the work performance of public high school teachers in Hulu Sungai Selatan district. Lentera Jurnal Pendidikan, 13(1). doi:10.33654/jpl.v13i1.350

Sulaxono, L. R. (2020). Relationship of transformational leadership and work motivation through discipline and teacher performance. Journal of K6, Education, and Management,

57-65. doi:http://dx.doi.org/10.11594/jk6em.03.01.08

Suranto, A. (2005). Office communication "communication principle to improve office performance. Yogyakarta: Media Wacana.

Suriansyah, A. (2014). The relationship of school culture, communication, and work commitment to the performance of. Cakrawala Pendidikan, 33(3), 358-367. doi:https://doi.org/10.21831/cp.v3i3.2380

Susipta, I. (2015). The influence of morale and communication on the performance of education personnel. Journal Management of Gajayana, 12(2).
Suyomukti, N. (2016). Introduction to communication science. Yogyakarta: Ar-Ruzz Media.

Szostek, D. (2019). The Impact of the Quality of Interpersonal Relationships between Employees on Counterproductive Work Behavior: A Study of Employees in Poland. Sustainability, 11, 1-33. doi:10.3390/su11215916

Wahyuni, S., S. E., \& Retnowati, R. (2016). The relationship of interpersonal communication, working motivation and transformational leadership to teachers' job satisfaction. International Journal of Managerial Studies and Research, 4(8), 89-93. doi:http://dx.doi.org/10.20431/23490349.0408007

Weakliem, D. L., \& Frenkel, S. J. (2006). Morale and workplace performance. Work and Occupations, 33(3), 335-361. doi:https://doi.org/10.1177/0730888406290054

Willis, M., \& Varner, L. (2010). Factors that affect teacher morale. Academic Leadership: The Online Journal, 8(4), 1-5.

Yulianti, \& Muhidin. (2017). Study of teacher compensation and work spirit. Journal of office management education, 2(1), 1-10 